Article

\title{
The Catholic Charismatic Renewal and the Catholicism That Remains: A Study of the CCR Movement in Rio de Janeiro
}

\section{Silvia Fernandes}

Multidisciplinary Institute, Departament of History, Federal Rural University of Rio de Janeiro, Rio de Janeiro, Av Gov. Roberto Silveira, Centro, 26020-740 Nova Iguaçu, Brazil; fernandes.silv@gmail.com

Received: 28 April 2019; Accepted: 20 June 2019; Published: 23 June 2019

\begin{abstract}
There are few empirical studies on the Catholic Church's loss of followers in the state of Rio de Janeiro and, more generally, on the decline of Catholicism in Brazil. Drawing from the Weberian theses of disenchantment and religious rationalization, this article explores the situation of Catholicism in four municipalities in this state. Working on some strategically selected municipalities and parishes, we conducted fieldwork and in-depth interviews with Catholics who are linked to the Charismatic Renewal (CCR). Our study assesses the hypotheses that (i) the emergence of the CCR favored the process of Catholic resistance in some municipalities, and (ii) that religious adherence and deinstitutionalization are two effects of a rationalization process. The qualitative results of the study showed that charismatic prayer groups became more diluted by the expansion of the Communities of Life and Alliance (Comunidades de Vida e Aliança). Nevertheless, the Catholic Charismatic Renewal still guides the Catholic ethos in the state.
\end{abstract}

Keywords: Brazil; Catholic Charismatic Renewal (CCR), Charismatics; Rationalization; Rio de Janeiro; Urban Catholics

\section{Introduction}

This study uses census data to explore qualitatively the Catholic Charismatic Renewal (CCR) in the state of Rio de Janeiro, whose proportion of Catholics-45.8 percent-is the lowest in Brazil. This type of research is particularly relevant in light of the persistent decline in the number of Brazilians who declare themselves Catholics. With each population census, researchers have examined the factors that are leading to this decline. However, few have studied the kind of Catholicism that still remains after desertion, especially in a state with the lowest proportion of Catholics in the nation.

The Catholic Charismatic Renewal has grown rapidly in Brazil. Although charismatic spirituality resonates with the subjective demands of the faithful, many leaders within the Catholic Church perceived in the CCR a way to confront the advance of Pentecostalism. Some Brazilian bishops and priests have assumed that CCR helps to curtail the migration of believers to evangelical churches (Carranza 2000).

This article seeks to expand the understanding of the dynamics of religious adherence in contemporary Brazil, focusing on some key cities of state of Rio de Janeiro. It analyzes beliefs and forms of belonging among Catholic Charismatics in the cities of Campos dos Goytacazes, Silva Jardim, Laje do Muriaé, and Rio de Janeiro. Later on, I will explain the criteria for choosing these municipalities among the state's 92 cities.

The increasing religious pluralism in Brazil serves as a wake-up call for the Catholic Church. For centuries, it was the religion with the greatest number of adherents. While Catholicism continues to be the religion of the majority of Brazilians, the proportion of Evangelical Protestants has jumped 
exponentially from single digits in the 1950s to 22 percent of the country's population in the census of 2010. Pentecostal churches, many of which have a strong proselytist modus operandi, account for most of the Protestant growth. Thus, following Stark and Finke (2000), I argue that secularization in Latin America has an inverse effect to what has occurred in Europe, where religious disestablishment has been accompanied by a decline in religious affiliation and church attendance across the board (Norris and Englehart 2004). In contrast, in Brazil and other Latin American countries, the intensification of religious pluralism has increased the religious supply, threatening the hegemony of the Catholic Church through the proliferation of actively proselytizing expressions of Christianity. The religious pluralism that characterizes Latin American societies pivots around the formation of more flexible and non-exclusive religious identities that can cause the rejection of a particular religious institution or of religion altogether, as well as favor the total or partial adherence of individuals to certain belief systems.

We can explain the effects of religious pluralism in Brazil through Weber's thesis of the disenchantment of the world: with the coming of modernity, religious rationalization gains plausibility, in the sense that there is a strengthening of an ideal-typical moral, cognitive religion that opposes magic and tradition. In other words, religious differentiation has not necessarily led to religion's, and more specifically Catholicism's, decline in the public sphere, but it has produced religious beliefs, practices, and institutions that concentrate on the methodical search for the well-being and salvation of the individual, rather than on the reproduction of binding collective "chains of memory" (Hervieu-Léger 2000). This is what account for the formation of flexible and non-exclusive forms of religious identity. In order to confirm that, indeed, this thesis applies to the Brazilian case, we need to confront it with empirical case studies that exemplify the crisis of Catholicism in the country. The Catholic Charismatic Renewal is both a response and a symptom of this process of religious differentiation and rationalization. That is why the examination of the specific reality of the state of Rio de Janeiro is very helpful to understand the CCR sociologically as a type of Catholicism that persists and that has, to some extent, shaped the way of being Catholic in Brazil.

\section{Catholicism in the State-Continuities and Characteristics in the Case Studies}

The state of Rio de Janeiro is composed of 92 municipalities, the majority of which contain a proportion of Catholics below the national average -64.6 percent in the census of 2010. However, in some of these municipalities, the proportion of Catholics exceeds the national average, reaching over 80 percent. To illustrate the complexity of the situation of Catholicism in the state, take the municipality of Silva Jardim, situated in the northwest. According to the 2000 census, it had the lowest proportion of Catholics (33.3 percent). In the 2010 census, that proportion fell further, reaching just 26.8 percent. These statistics confirm an important tendency: religious mobility among Catholics has intensified with each passing decade, resulting in a change in the religious identity of the faithful in the direction of Pentecostal churches or towards the condition of "no religion" (Fernandes and Pitta 2006).

In contrast to Silva Jardim, Laje do Muriaé, located to the northwest, on Rio de Janeiro's border with the neighboring state of Minas Gerais had 82.9 percent of Catholics in 2000, making the municipality one of the strongholds of Catholicism in the state. Although Laje maintained that status in the 2010 census, there was an important drop in the proportion of Catholics, who represented 77 percent of the population in that municipality.

Focusing on Silva Jardim and Laje do Muriaé covers the spectrum of Catholic affiliation within the state, from the lowest to highest, allowing for potentially fruitful comparisons and contrasts regarding the Catholicism that remains.

Amid the religious diversity in the State of Rio de Janeiro, I would like to offer a few words to justify the choice of my two other case studies-the municipalities of Campos de Goytacazes and the capital. In the first case, it is a city whose diocese rejected in 1970 the changes ushered in by the Second Vatican Council and maintains a profoundly traditionalist profile. This traditionalism is an important variable to consider as I study the type of Catholicism that dominates in the municipality even in the face of decline. In turn, the choice of the eponymous capital of the state is justified by the fact that, due 
to its history and size, the city of Rio de Janeiro has an enormous influence not only on the region but the country.

Given the heterogeneity of indices of Catholic adherence in the region, it is important not to conclude that the census data provide sufficient evidence to predict with full certainty the future of Catholicism in the country. We need to explore qualitatively the multiple salient variables, actors, scenarios, and processes to construct a more nuanced picture of what is taking place. The four case studies I chose are not intended to provide a comprehensive view or to serve as a statistically representative sample of Catholicism in the state. Rather, because of their particular histories, the varying proportions of Catholics, and their size and location (as large or small cities), these field sites may reveal some important clues about the current dynamics of Catholicism in Rio de Janeiro.

In terms of methodology, I should also say that, although the selection of parishes that were researched within each of the cities followed a sampling criterion, the study is not quantitative, and the choice I made did not involve the variables of age or gender. The mention of these variables throughout the article aims only to situate the reader in regard to the informants' profiles.

Consider in the Table 1 below the proportional distribution of Catholics in the municipalities.

Table 1. Proportion of Catholics in the Selected Municipalities in the State of Rio de Janeiro.

\begin{tabular}{ll}
\hline Cities & Catholics (\%) \\
\hline Campos dos Goytacazes & 50.1 \\
Laje do Muriaé & 77.0 \\
Rio de Janeiro & 51.0 \\
Silva Jardim & 26.8 \\
\hline Source: IBGE-Census 2010-Prepared by author.
\end{tabular}

Data from these municipalities demonstrate the heterogeneity of Catholicism in the state and raise some pertinent questions. What kind of Catholicism survives in a city like Laje do Muriaé whose proportion of Catholics is above the national average? What structures and symbolic dimensions ensure the high proportion of Catholics in times of institutional crisis and a generalized loss of believers? And in the case of Silva Jardim, what are the main socio-cultural factors that condition the low adherence to Catholicism? What kind of religiosity and forms of bond do Catholics who persist in the institution experience?

Questions such as these guided the study. Belonging to Catholicism is not simply the result of religious factors, but it is also affected by objective situations related to material life, as well as by subjective issues, such as the desire to feel welcomed in a community or integrated into a group. These dimensions of life can therefore strengthen or weaken the religious bond. In addition, there can be different modes of assuming a Catholic identity in various urban settings in response to local institutional proposals. As the Catholic Church acknowledges that there are multiple and evolving ways of living within its system of beliefs, it establishes with its supporters relationships that can range from conflict to accommodation and assimilation. The strength and weakness of the Catholic Church resides in this dynamic: in the tension between maintaining and renewing the original principles of its institutional identity, the Church incorporates different proposals of spiritual experience, managing emerging conflicts in a process of assimilating internal differences. During the 1990s, the National Conference of Brazilian Bishops (CNBB) was suspicious of the CCR because it felt its spirituality and style resembled too closely those of Pentecostalism (CNBB 1994). In a very public snub, Father Marcelo Rossi, a widely popular "singing priest" considered a leader in the Charismatic movement, was not invited to the events around former Pope Benedict XVI's visit to Brazil ${ }^{1}$. Currently, resistance to the CCR is rarer among the hierarchy. In fact, the Catholic bishops in Brazil have accepted the movement

1 See: http://g1.globo.com/Noticias/PapanoBrasil/0,,MUL34827-8524,00.html. Accessed on 10 June 2019. 
as a viable model of being Catholic ${ }^{2}$. Pope Francis's changing attitude concerning Charismatics is illustrative on this point. After critiquing the movement for trivializing liturgy as a "carnival", he publicly recognized during a trip to Brazil the CCR's valuable contributions to evangelization and the life of the Church ${ }^{3}$.

Previous studies have shown that depending on the city, the CCR has achieved varying degrees of presence and assumed different characteristics (Fernandes 2009). This article intends to understand these specificities in the municipalities studied.

\section{The Catholic Charismatic Renewal and the Communities of Life and Alliance (Comunidades de Vida e Aliança)}

The first charismatic prayer groups were formed in Brazil in 1968 in the city of Campinas, in the state of Sao Paulo, by a Jesuit (Fernandes 2009).

Since then, research on the emergence of the Catholic Charismatic Renewal in Brazil has greatly expanded, focusing on the movement's ability to promote the return of estranged Catholics. (Carranza 2000; Fernandes 1996; Mariz and Machado 1994; Mariz 2001, 2003, 2005; Prandi 1997; Steil 2004). ${ }^{4}$ The hypothesis is that the spirituality of the CCR and its more effusive and emotional rites promote a new enthusiasm among Catholics, leading to a rapprochement with a church that they were no longer attending.

Within the territorial and social context in which we undertook our research, the city of Rio de Janeiro has especially witnessed over the last decades a process of "charismatization" that has attracted hundreds of people to the parishes and communities that have implemented CCR practices such as healing and liberation Masses (missas de libertação e cura), seminars on the life in the spirit, exorcisms, praise, and glossolalia. In the late 1980s and early 1990s, the movement in Rio was characterized by meetings in prayer groups. From the mid-90s onwards, a deepening of lay involvement in the movement began to take place. Many young people eager for a more sustained charismatic spirituality began to form prayer communities that, also originating in Campinas, grew rapidly throughout the state and country. The prayer groups that were the original nuclei of the CCR began to coexist alongside and, gradually, coalesced with these new communities, leading eventually to what would be called Communities of Alliance and Communities of Life in the Holy Spirit.

The emergence of the CCR has produced two antagonistic effects in Brazilian Catholicism in the last thirty years. The first one relates to the expansion of the movement from the mid-80s and throughout the decade of ' 90 s, spreading from the middle class to the working class and lower-income groups. ${ }^{5}$ In this period, the CCR transforms the face of Catholicism, especially in large cities, bringing it very close to Pentecostalism, in a way that intensified a kind of double belonging among Catholics, as well as encouraging a circulation of the faithful and a religious mobility across various forms of being Christian. In turn, this mobility produced a decrease in the number of people who declare themselves as Catholics in census research. The second contradictory effect takes place from the end of the 1990s to the present: the strengthening of Catholic identity through the heavily-mediatized performance of young and charismatic "singing priests", such as Marcelo Rossi and subsequently Father Fábio de Melo.

2 See: http://cnbbsul1.org.br/regional-sul-1-recebeu-nova-coordenacao-regional-da-renovacao-carismatica-catolica/. Accessed on 9 June 2019.

3 See: https://www.rccbrasil.org.br/espiritualidade-e-formacao/palavra-do-papa/1232-papa-francisco-a-renovacaocarismatica-e-uma-corrente-de-graca-para-a-igreja.html/. Accessed on 10 June 2019.

4 The literature on the CCR in Brazil is vast and I chose to concentrate on authors who have focused on it more consistently.

5 In 1994, I conducted a case study on the arrival of the CCR to a Catholic community located in a favela in Rio de Janeiro. The conflict between the local progressive priest and the leader of the prayer group resulted in the departure of the leader of the charismatic community to found a Pentecostal church called the Renewal Christian Community. Several Catholics who participated in the prayer group followed the charismatic leader and became Pentecostals. Some of them, however, subsequently returned to Catholicism (Fernandes 1996). 
Currently, any inhabitant in Rio de Janeiro is bound to encounter countless cars with stickers asserting: "I'm happy to be a Catholic." The expansion of the religious market is also evident, ${ }^{6}$ with a cornucopia of Catholic objects and symbols-images of Mary turned into stickies surrounded by the rosary, images of saints, bracelets, paintings, clothing with religious themes-all offered on Catholic websites of charismatic orientation and in the stores of religious products. Of course, the use of religious images and symbols is not new in Brazil. However, objects for bodily use, such as wristbands and T-shirts with inscriptions that affirm Catholic identity in a more intimate sense, have become more widespread with the CCR. While traditional Catholic stores, such as the "Liturgical Apostolate" and "Paulinas" already sold religious objects, this market expanded exponentially at the hands of the Charismatic movement. Carranza (2000) clearly confirms this trend in her analysis of the company "Maria Collection by Evang-Line, products that evangelize", based in the city of São Paulo. Operating with the motto: "Everything that is sacred prospers", Maria Collection "has launched more than 1500 products in the market, such as T-shirts, books, caps, rosaries, stickers, [and] accessories for personal use. The Maria Collection defines itself as a community of charismatic alliance that has discovered its vocation as a Christian enterprise to evangelize with quality" (Carranza 2000, p. 291).

In Brazil, the expansion of these symbols and sacralized accessories in urban spaces and outside pilgrimage sites and shrines can be attributed to the Catholic Charismatic Renewal. As Carranza (2000, pp. 291-92) demonstrates, the phrases on T-shirts seek to confront contemporary society in an intimate tone that expresses the Charismatic worldview. For charismatics, if "the world is taking people to consumption, we are going to get people to wear a shirt that will scream that Jesus Christ is the Lord" (Carranza 2000, p. 292). According to Carranza, some of the most common slogans printed on T-shirts include "Jesus-best gift!" "Jesus Christ—salvation for real!"

The CCR has been particularly instrumental in this commercialization of Catholic religious objects in Rio de Janeiro. In this sense, a charismatic ethos has emerged as a key supporting pillar of Catholic identity, an ethos that is constructed and diffused in a particular way through television programs, mass concerts of singing priests ${ }^{7}$ and the Internet and the social media ${ }^{8}$.

We have two seemingly contradictory dynamics. On the one hand, there is a weakening of Catholic adherence, experienced more intensively in the state of Rio de Janeiro. On the other hand, in the Catholicism that remains, there is a notable charismaticism that sets the tone for religious celebrations and pastoral activities, with the Communities of Alliance and Life in the Holy Spirit serving as the paragon of this charismatic ethos. The Communities of Alliance are formed by laypeople who adhere to charismatic spirituality. They have common projects of Catholic belonging and evangelization, but the members do not live in the same house and stay connected with their families of origin. ${ }^{9}$ The Catholic hierarchy calls these communities "Associations of the Faithful" (Associações de Fiéis). The second

6 Braga (2004) argues that the sale of religious products by TV Canção Nova (New Song), a high-profile media initiative connected with the CCR, aims to ensure the sustainability of the channel without entering into a market logic that would bring secular advertisements to religious TV and contradict the asceticism promoted by charismatics. For Braga, the orientation of this TV would be based on Providence and the commitment of the faithful rather than on the logic of the market. Certainly, this thesis can be problematized, as the CCR is one of the Catholic movements that are most entwined with the market, either through the expansion of its religious products fairs, such as the Catholic Expo, or by the use of cutting-edge evangelization technologies.

7 One of the first "singing priests" in Brazil was José Fernandes de Oliveira, known as Father Zezinho, whose first record came out in 1967. His musical style and model of disseminating Catholic music differ strongly from so-called media priests, such as Father Antônio Maria, Marcelo Rossi, Fabio de Melo, and Reginaldo Manzotti, to name the most popular. Unlike Father Zezinho, all these media priests have a religious trajectory linked to the CCR.

8 Although the Catholic Church in Brazil has a long tradition in radio and TV communication, the CCR triggered the veritable expansion of these media. Thus, in 2019, there are two charismatic Catholic broadcasters: Rede Século XXI, founded in 1999, and Canção Nova, founded in 1989. Rede Vida was inaugurated in 1995 and has a broader programming. In turn, TV Aparecida, which was founded by Redemptorist priests in 2005, was ranked as the seventh broadcaster with the largest audience in the country. See: https://tvefamosos.uol.com.br/noticias/ooops/2016/11/08/em-outubro-audiencia-da-tvaparecida-supera-multishow-discovery-e-warner.htm.

9 For an illustration, see the website of the Bom Pastor community, located in the neighborhood of Copacabana in Rio de Janeiro: http://www.combompastor.com.br. Accessed on 12 December 2018. 
type, the Communities of Life in the Holy Spirit, are formed by Catholics who, inspired by the CCR's spirituality, renounce their personal plans and share the same house, dedicating themselves exclusively to evangelical mission (de Oliveira 2004). In their daily lives, the members of these communities follow religious vows of poverty, chastity, and obedience that are common in traditional Catholicism.

According to Mariz (2009), these new communities are movements of lay people, inspired by the Second Vatican Council, who seek to do missionary work of evangelization, following their vocations or individual callings, which are called charismas (gifts of the Holy Spirit). The Communities of Life attract young people in particular. They have diverse styles and charismas, while maintaining common ideals. For example, there are clear differences in the style, religious experience, clothing, and hierarchical and organizational structure between Canção Nova and A Toca de Assis. The former does not require its members to adopt distinctive habits or garments to mark their religious affiliation. In contrast, in the latter, the young dress in the manner of Francis of Assisi, including the tonsure (Fernandes and Froehle 2011). ${ }^{10}$ Young members of the Toca de Assis move away from formal education, even to the point of abandoning their studies and adopting poverty as a radical experience, living with the homeless and welcoming them in "Fraternal Houses". It is worth noting that the Toca de Assis maintains itself as a life community, while, at the same time, forming the Institute of the Sons and Daughters of Poverty of the Blessed Sacrament (Instituto dos Filhos e Filhas da Pobreza do Santíssimo Sacramento), which is recognized by diocesan law.

Groups like Canção Nova and Toca de Assis actively announce the presence of the CCR in the territories in which they settle. In the city of Rio de Janeiro, there are several Communities of Alliance and Life in the Holy Spirit and many of the recently-ordained priests belong to the CCR, a fact that can further catalyze the expansion of charismatic spirituality in the region. Young people's attraction to the priesthood in the metropolitan region of Rio de Janeiro is greatly favored by the spiritualist proposal of the CCR, although the candidates express that they do not intend to be priests for a single Catholic movement, a position that demonstrates adherence to the discourse of unity in plurality in the Church at large (Fernandes 2010).

With these introductory remarks, I now turn to the simultaneous process of religious desertion and adherence in the state of Rio de Janeiro, taking into account the Weberian theses on disenchantment and religious rationalization, in order to understand expansion of the Catholic Charismatic Renewal through prayer groups and Communities of Alliance and Life in the Holy Spirit.

\section{Theoretical Considerations and Working Hypotheses}

The study of the situation of Catholicism in the state of Rio de Janeiro is embedded in the debate about modernity, the constitutive axis of the social sciences, which became an "articulating pole in the study of religion" (Camurça 2008). Thinking about modernity and the religious sphere immediately refers us to the Weberian theory of rationalization, namely, to the fact that religion survives in modern life as a rational proposal within the field of values. As Mariz (2007) argued, Max Weber did not adopt the evolutionary perspective that was common in his time, one that proposed universal social causes operating differently throughout history. Rather, for Weber, it is important to consider the relevance of the historical method in social analyses, and it is this method that he brilliantly uses when articulating his theory of rationalization. Thus, he affirms that "rationalism is a historical concept that encompasses a whole world of diverse components." (Weber 1999). ${ }^{11}$

Rationalization for Weber relates to the definition of means and ends; it is the predominance of systematic ways of organizing life in order to achieve the goals. In the religious field, he argues that the Baptists sects and strict predestinationist Calvinists were the groups that most contributed to religious

10 In the tonsure cutting, the hair is cut at the top of the head and in the lower part preserving the strands just around the head.

11 The citation comes from the 14th edition published in Brazil by Pioneira Press. The first edition dates from 1967 by the same publisher. 
demystification and the disenchantment of the world, as they devalued the sacraments as a means of salvation (Weber 1999).

I find the Weberian concepts of rationalization and disenchantment relevant to the analysis of the historical decline of Catholicism and the paradoxical growth of charismatic communities in the State of Rio de Janeiro, for two theoretical-analytical reasons:

(1) I contend that the rationalization process in Brazilian society occurs simultaneously with an increase in individualization, and that both processes are intrinsically related. Thus, charismatic spirituality with its strong individualistic tenor and religious deinstitutionalization, that is, the loosening of institutional religious affiliation, are two effects of the same rationalizing process.

(2) Several studies counterpose the two theses: (a) the re-enchantment of the world in the sense of a return of the sacred (Souza 1986), as new religious movements emerge in the attempt to create meaning in the vacuum left by rationalization; (b) a reaffirmation of the Weberian thesis of secularization, since the new religious movements tend to be highly rationalized and individualistic. Nevertheless, few comprehensive empirical studies in Brazil test the validity of (either of) these theses. As we shall see, these two theses offer a viable explanation of the charismatization of Catholicism in the state of Rio de Janeiro in response to increase religious pluralism.

In particular, the Weberian concept of the routinization of charism (Weber 1998), which points to the institutionalization of the spiritual gifts, becomes relevant when thinking about the new charismatic communities. As Weber (1998) argued, there are several reasons that drive the routinization of charism, among them the ideal and material interests of the adherents in the persistence and permanent vitality of the community. Along these lines, when analyzing the CCR, Mariz (2003) reminds us that the new modalities of religious experience the movement encourages necessarily imply new ways of organization of traditional institutions.

Thus, the most emblematic illustration of this routinization of charisma among the new communities would be the already-mentioned Toca de Assis. It arises spontaneously out of a reanimation of age-old Catholic beliefs and practices and it is quickly institutionalized (Fernandes and Froehle 2011)

\section{The Results-The CCR in Different Contexts ${ }^{12}$}

\subsection{Campos de Goytacazes}

As a capital in the northeastern region of the state, Campos dos Goytacazes is the most important city in the area. The urban area concentrates most of the 464,000 inhabitants in region, with only 10 percent of them living in rural areas.

The Diocese of Campos dos Goytacazes became known for a schism that occurred during the Second Vatican Council. In several parishes of the Campista diocese, conservative groups favorable to the Council of Trent opposed Vatican II reforms. Bishop Antonio de Castro Mayer, who oversaw the diocese from 1949 to 1981, strongly resisted these reforms. The conflict between traditionalists and progressives was only solved in 2007, with the publication of a document entitled Motu Próprio Summorum Pontificum by Benedict XVI (Loura 2014).

The CCR arrived to Campos dos Goytacazes in 1972, when the diocese was still under the jurisdiction of Bishop Mayer, although he was opposed to the movement. Here, it is interesting to note that Mayer's traditionalism was not aligned with the CCR's. However, reports of the time appear to indicate that the bishop consented to the movement behind the scenes, since he asked charismatics to gather in their houses so that he would not have to see their meetings (Loura 2014).

12 From 2010 to 2012, I conducted in-depth interviews in 11 parishes in Rio de Janeiro; 2 parishes in Campos dos Goytacazes; 1 parish in Silva Jardim; and 1 parish in Laje do Muriaé, totaling fifteen parishes investigated. This sample amounts to $5 \%$ of parishes in Rio de Janeiro; 10\% in Campos dos Goytacazes and 100\% of parishes in Laje do Muriaé and Silva Jardim.It should be noted that the size of the parish sample took into account the availability of resources for research in each city. The interviews were analyzed through NVivo software. 
In fact, Bishop Mayer's attitude toward CCR was a catalyst, opening the space and fertile ground for the movement's expansion.

In this town, we studied two randomly selected parishes-Saint Benedict and The Sacred Heart of Jesus-as well as two charismatic communities, a Life Community called Eternal Alliance (Aliança Eterna) and the Fountain of Living Water (Fonte de Água Viva) Alliance Community. Practices in these two communities included healing and liberation meetings (encontros de cura e libertação). A charismatic leader of national stature led one of these encounters. His discourse emphasized the dimension of inner healing, an extremely valued narrative in the CCR. We also noticed an emphasis on combating Satan, a practice that brings the CCR close to Neo-Pentecostal churches in Brazil. Holding a cross in his right hand, the leader said in a loud voice:

By the five wounds [the stigmata in Jesus Christ's hands], I break from/cut down and renounce the evil forces. I renounce Satan, father of all lies. [ ... ] By the blood shed [by Jesus Christ], by the intercession of the Virgin Mary, I break from/cut down prostitution and adultery, homosexuality, partying, in the name of Jesus Christ I renounce. By the five wounds, I break from/cut down and renounce esotericism, the Masonic Church, Spiritism, the horoscope [ ... ]. By the five wounds, break from/cut down and renounce witchcraft, Satan, evil spirits, the evil eye and evil works (despachos). I break from/cut down and renounce all sorts of consecrations against me, all spirits that lean on me (encostos) [ ... ] (Healing and Liberation Meeting, Campos dos Goytacazes, 2011). ${ }^{13}$

In another parish, a charismatic leader preached about prosperity and healing. These are two elements also prominent among Neo-Pentecostals.

If you have a document to sign tomorrow, sign it, because the spirit is working on it. If you are looking with concern at your promissory notes and think that the only exit is to end your life, remain calm; the Holy Spirit is acting [on your behalf]. If you are not selling anything in your store, don't worry. Tomorrow you will see, it's going to rain people in your store. Everything is possible if you believe [ ... ] Nothing is possible if ye hath no faith. You're the one with the tumor? That tumor is disappearing. (Healing and Liberation Meeting, Campos dos Goytacazes, 2011). ${ }^{14}$

In the group of 15 interviewees, ten were women and five were men, all aged between 20 and 60 years. Regarding schooling, the group is divided among those with undergraduate degrees, secondary education, and elementary school. They all come from practicing Catholic families and one of our female informants indicated that her mother frequented several religions until she returned to Catholicism. We also noticed that they had a low doctrinal formation in Catholicism, with, at best, a basic knowledge of the religion.

All the respondents are charismatic Catholics and most them claimed to have always been Catholics, even if they were hardly active. They feel that their participation intensified after joining the Catholic Charismatic Renewal or a Community of Life and Alliance. Indeed, they all participate in prayer groups and one of these communities. For some respondents, the main difference between CCR and the communities of life lies in the type of formation. They understand the CCR as a general movement with a specific training, using more intensely the "charismas" and "gifts of the Spirit." In turn, the communities act according to the own charismas, with some communities having their own prayer groups.

Five informants who have participated more effectively in the church in the last ten years mentioned that they returned to Catholicism through the CCR. In this group, there were two former

13 Research Report: "The crisis of Catholicism in the state of Rio de Janeiro and the paradoxical advancement of the New Religious Communities."

14 Research Report: "The crisis of Catholicism in the state of Rio de Janeiro and the paradoxical advancement of the New Religious Communities." 
Spiritists who converted to Catholicism through the Catholic Charismatic Renewal. They found the CCR through an invitation from other participants who are either friends or family members. However, a factor that encouraged them to attend prayer groups was the need to seek solutions to everyday problems, such as depression and several illnesses.

For the interviewees, the main reason to join and remain in Catholicism is tradition, both in the sense of assimilating the official narratives and in terms of maintaining the family religious legacy. On the one hand, they argue that the Catholic Church is the true church founded by Christ and this motivates them to remain. On the other hand, they affirm that the faith of their parents made them Catholics. The hierarchy, the sacraments—especially, the Eucharist-the devotion to Mary, and the "freedom that the church gives to the faithful" appear in their narratives as important symbolic elements for preserving the bond with Catholicism and motivating them to live as Catholics.

The charismatic Catholics in Campos also stressed that the practice of "Eucharistic worship" is an important element for the maintenance of their faith. Thus, for these charismatics, the main defining difference between Catholicism and other Christian traditions is the Eucharist, including the legitimate and exclusive power of priests to transform the elements.

\subsection{Laje do Muriaé}

The city of Laje do Muriaé has only 7487 inhabitants, residing mainly in the urban part of the city. Laje was featured in the media as a city that shrank in the 2000-2010 decade. ${ }^{15}$ This fact contrasts with the dynamics of local Catholicism. While the city shrinks, Catholicism remains robust, mainly driven by intergenerational transmission.

The city's low index of socio-economic development-with only 15 percent of the employed population receiving an average of less than two minimum wages (the equivalent to $\$ 700$ dollars)—reflects modernity's tenuous hold. This fact, however, did not prevent the incorporation of the Charismatic Renewal into Laje do Muriaé's Catholicism. The movement brings together many young people who have adopted a moral conservatism that involves an extreme appreciation of virginity, criticism of the "sensuality of girls", and the "promiscuity of the boys", in addition to establishing a distinction between "us" and "the world". The representation of society or "world" as a reality that requires conversion is recurrent in the narratives of the charismatics who participate in both prayer groups and Communities of Life and Alliance.

It is important to highlight that Laje belongs to the Diocese of Campos of the Goytacazes, which, as we saw, is characterized by a traditionalist Catholicism. Ten of the charismatics we interviewed complained about the city's political culture, because there is a perpetuation of political representatives in influential positions, a condition that generates preferential treatment and favors for certain sectors. They also complained about the economy, since there are only three main sources of employment in the city: city hall, agriculture, and trade. Because of this, there are few work options and the population tends to migrate to other cities in search of better living conditions.

The parish surveyed—Our Lady of Mercy—is the only one in Laje do Muriaé. Founded in 1861, it now contains 12 chapels.

The Figure 1 above shows the style of prayer of young people that is very typical of the CCR, with an emphasis on bodily expressions in the act of prayer and music, generally sung by the leader of the meeting. The parish is one of the city's landmarks, and is situated on the top of a small hill, forming a bucolic landscape that is characteristic of many cities of the interior of the country. Commercial life is clustered along a single street that cuts through the urban area. The church is an important space of sociability in light of the few places available for leisure and cultural activities.

15 See https://goo.gl/AkNJHA. Accessed on 20 April 2018. 


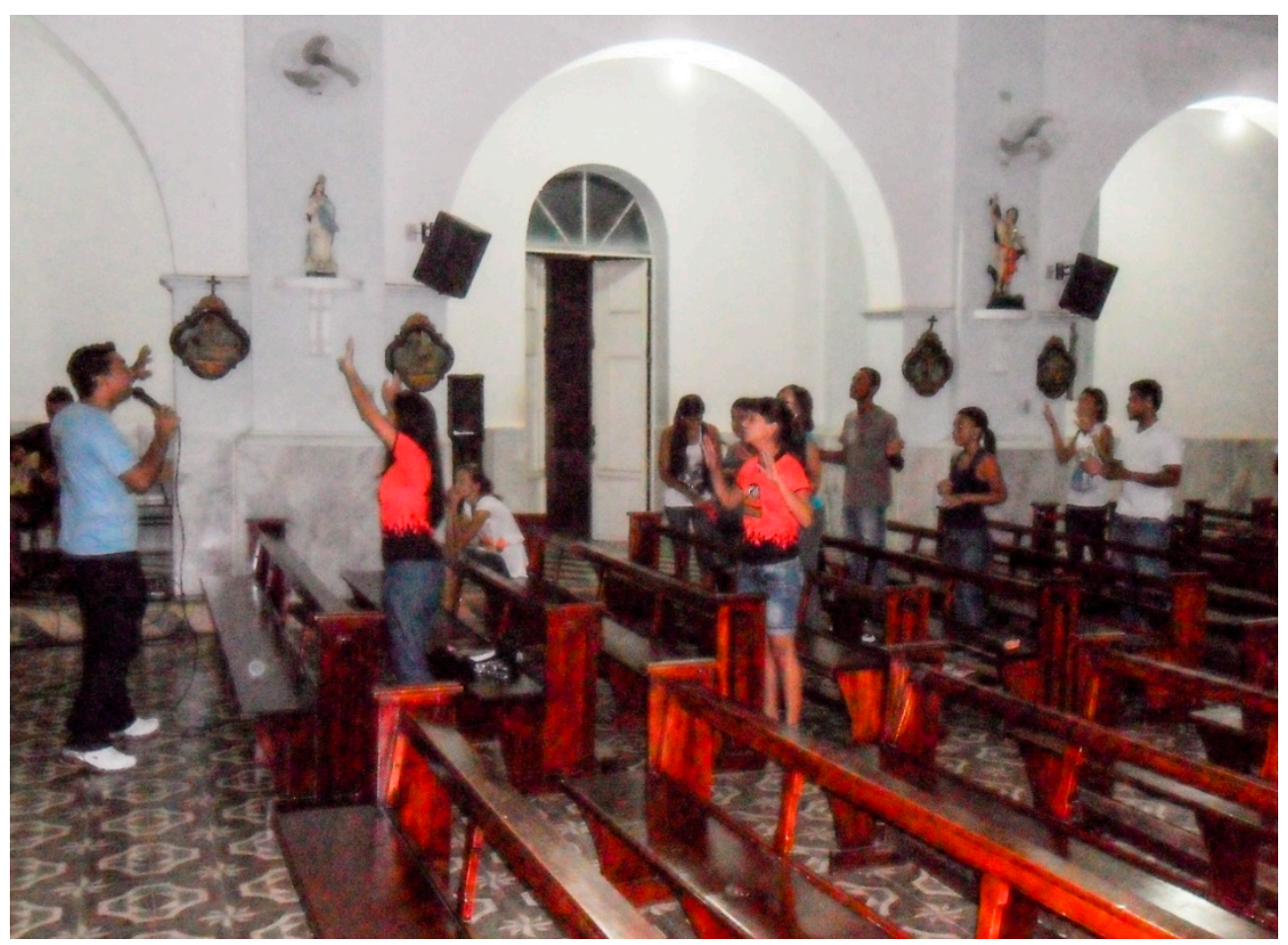

Figure 1. Source: Research collection: Charismas and Institutions-The Crisis of Catholicism in the state of Rio de Janeiro and the Paradoxical Advancement of New Religious Communities. Author: Sílvia Fernandes-Meeting of the Aliança de Misericórdia Prayer Group. 2012. ${ }^{16}$.

In this city, we interviewed seventeen people, seven men and ten women aged between 20 and 45 years. We witnessed many signs of transmission of Catholicism to new generations through symbols. For example, we saw many young people queueing for Confession, upon leaving their public schools. Children who play in the Main Square make the sign of the cross as they pass by the temple, in a typical gesture of traditional Catholics that is apparently being inculcated in the new generations. However, it is not possible to ascertain that the religious bonds passed on to these children will remain unchanged throughout their lives.

Although the parish of Laje has many of the traditional Catholic groups, such as Apostolate of Prayer, Ministry of Tithing, and Legion of Mary, the CCR has the oldest group in the parish, Água Viva (Living Water), which has been in existence for about thirty years and is able to gather about 80 young people at its meetings. The other prayer group, called Aliança de Misericórdia (Covenant of Mercy) was founded 15 years ago and currently brings together about 50 young people. This group originated from a spiritual retreat called Maranathá, in which the participants report to have received a "revelation" from the Holy Spirit that the group should be created.

The local parish priest is of charismatic orientation, but the CCR competes with several other movements in Laje do Muriaé. The presence the Heralds of the Gospel, a traditionalist international lay association that gained Church approval in 2001, is considered controversial by the interviewees since this group has assumed the leadership of one of the chapels of the municipality with the support of a priest and two nuns. Charismatics are uncomfortable with this division, since it is the only chapel that is led by another priest.

There is low religious mobility among the interviewees. However, a primary school teacher stated that, when she was a child, she attended a Kardecist Spiritist center with her mother, who declared

16 Research Report: "The crisis of Catholicism in the state of Rio de Janeiro and the paradoxical advance of the new religious communities." 
herself a practicing Catholic. The fact demonstrates the existence of dual belonging among traditional Catholics, revealing that some current members of the CCR remained in Catholicism, but have adopted a double belonging. This is a typical attitude in Brazilian religious culture, one in which Catholicism can be practiced alongside other religious expressions without guilt on the part of the adept.

Tradition was a recurrent theme among the interviewees. Many of them indicated that they are Catholic because they are following the same religion as their parents. They also tended to value the figures of Jesus, the Holy Spirit, and Mary as the greatest symbolic sources to maintain their Catholic identity (Fernandes 2014). In addition, the informants mentioned the Eucharist, the Bible, and the doctrine of the Church as Catholicism's most attractive elements. In fact, they also consider Catholic doctrine and the diversity of Catholicism as strong reasons for staying. This fact stands in contrast with research in large metropolises which has shown that doctrinal rigidity was one of the main reasons for the faithful to distance themselves from the Catholic Church (Fernandes and Pitta 2006).

When asked their opinion about the reasons why a large number of Catholics change religion nowadays, the faithful point out several reasons that are not always compatible. There are those who consider that being Catholic is difficult and see "weakness" in those who seek more flexible churches. In contrast, some think that people leave for more rigid religions because they have difficulty in imposing limits on themselves. According to these interviewees, the Catholic Church does not focus sufficiently on the imposition of moral boundaries and norms of conduct. Informants also pointed to the search for immediate solutions to everyday problems as a factor in Catholic desertions. Furthermore, some spoke in jest about the fidelity of the adherents, as in the case of a 31-year-old administrator who declared: "If the Church lost believers, it is because they were not faithful." This argument dovetails with the institutional perspective that adopts a rhetoric of appreciation of the "quality" of Catholics and not their quantity. Finally, a welcoming attitude, or rather, the lack of it, was also mentioned as one of the reasons for Catholics leaving the Church.

There are those who would like to see a less politicized church, one that can "hear Jesus" and less rational priests. The charismatic ethos, which, as we saw, is more strongly guided by an affective and emotional piety, informs this desire. Although Laje is a city in the interior of the country with few modern resources, the process of cultural globalization has touched and disrupted local life. For example, the informants have access to Catholic TV channels and radio stations and YouTube websites with reasonable frequency, and, even if in their narratives they accuse the fast-paced expansion of the technologies of communication of producing "individualism", these resources also favor the growth of religious belief systems and institutions.

Finally, the interviewees in Laje do Muriaé exhibit a traditionalist Catholicism with practices, such as the "adoration of the Blessed One (the Eucharist)", the disciplined teaching of doctrine and the Bible. Charismatics praise the CCR for being open to "the action of the Holy Spirit", promoting the "revival of the Church" and "strong prayer". They actively participate several pastoral initiatives with the expectation that the whole Church will eventually adopt the model of Catholicism proposed by the CCR. ${ }^{17}$

\subsection{Rio de Janeiro}

The city of Rio de Janeiro is the country's second megalopolis, serving as a national point of reference for cultural, political, economic, and religious matters. With a population of approximately 6 million inhabitants, Rio has the second highest GDP (gross domestic product) in the Brazil, only surpassed by São Paulo. The main commercial activity of the city is the service sector, although Rio's industrial pole is not negligible. The city is the headquarters for large state-owned, private national and multinational companies, including Petrobrás and the Vale do Rio Doce Company (CVRD), which are two of the largest in the country. Despite this, the employment rate is still low and only $41 \%$ of the

17 The analysis of Laje do Muriaé is partially published in Fernandes (2014, pp. 55-57). 
population have formal jobs, with an average monthly salary of four minimum wages, equivalent to $\$ 1500$.

Rio also houses the Globo Corporation, the largest media and communications group in Latin America. In cultural terms, the city has many major film studios, theatre companies, exhibition centers, music shows, and a wide range of bookstores. Known not only for its natural beauty, Rio de Janeiro has historic neighborhoods such as Lapa and Santa Teresa, recognized as strongholds for a very diverse artistic community.

In the religious realm, the city presents a "cosmopolitan" profile. Only 50\% of its inhabitants declare Catholicism as their religion, with the other half composed of Evangelicals, Spiritists, members of Afro-Brazilian religions, and people without religion. Most of these groups have significant temples and places of worship and congregation. Jews, Orthodox Christians, Hindus, Buddhists, Muslims, and adherents of Eastern religions are minority, not totaling even one percent.

Our sampling strategy of the parishes allowed for a balanced distribution of the research units, and the study was conducted in parishes located in diverse neighborhoods and regions of the city. We heard from 58 people-28 women and 30 men-in ten parishes and three Communities of Life and Alliance. Most of the interviewees fell in the 40 to 50 years age range, but we also interviewed youngsters (17 to 30 years of age) and adults aged 30 years and older than 60 . The group of Catholics studied comprised teachers, students, homemakers, metalworkers, and public officials, with schooling ranging from incomplete elementary school and to higher education.

Most of the interviewees came from Catholic families, with a low level of schooling and illiterate parents. However, there was a significant degree of religious pluralism and mobility within their families, which we also observed among Kardecist Spiritists, Protestants, and even atheists. Even among the charismatic Catholics participating in prayer groups or in the Communities of Life and Alliance, several of the interviewees had circulated through Spiritism and Pentecostalism before becoming Catholics through the CCR. The new identity is highly valued by both returning Catholics and those newly converted to Catholicism. They emphasize tradition, baptism in the spirit, and other mystical experiences, such as glossolalia, as strong dimensions of their current religious bond.

Tradition, faith, and doctrine emerged as the main aspects that motivate the faithful to be Catholics. In contrast to the more rural Laje do Muriaé, the belief in God, Jesus, the Eucharist, Mary and the Saints was mentioned less often as a motivation to assume a Catholic identity. Some stressed that God "helped in difficult situations" and "provided in times of need", bringing them closer to Catholicism. Rio Catholics expressed the vision of the Catholic Church as founded by Christ, a fact that animates their faith. Surprisingly, the Eucharist did not have the same relevance as a source of Catholic identity, although the sacrament appeared as a valued aspect of Catholicism that could attract new supporters.

Almost all of the informants in Rio regularly attend Sunday celebrations, pray the rosary, and perform Eucharistic adoration. A deacon emphasized the role of the Mass and Communion as essential for remaining in the Church in the following terms:

The Catholic Church's main element is the celebration of the Holy Mass, where all the mystery of salvation happens ... where Christ renews himself, where he makes himself present. I think the Catholic remains in the Church because of Christ himself who feeds him/her, when he says: "this is my body, this is my blood." 18

The CCR tends to emphasize Catholic tradition as a way to ensure its bond with the Church and to distance itself from Pentecostal movements which have many similarities in terms of style of worship and even theology (da Silva 2008). Thus, it is not surprising that almost all of the charismatics interviewed mentioned tradition as a motivation to be Catholic. According to Guerra (2003), the

18 Research Report: "The crisis of Catholicism in the state of Rio de Janeiro and the paradoxical advancement of the new religious communities." 
appreciation of Catholic identity is a new "marketing" strategy, deployed to combat the image that Protestants have in relation to Catholics, as "spiritually careless" (espiritualmente descuidados), "permissive" (permissivos), and "lacking commitment" (descomprometidos). The response to these stereotypes is:

The construction of a Catholic identity characterized by the "pride" (o orgulho) of being Catholic, in opposition to the ostentatious presentation of evangelical identities in general, which defines the "believers" (crentes) as "different", "pure" in a world of impure [people], "renewed" (renovados) and "children Of God", as opposed to a dwindling majority, classified by [these believers] as just God's creatures. (Guerra 2003)

And how did these Catholics encounter the CCR? Again, it was by the invitation of friends and family. However, religious events, retreats, and formation courses, as well as radio and TV programs were also cited ways to enter the CCR.

Although the Catholic Charismatic Renewal strives not to be compared to Pentecostal evangelicals, the narratives of conversion in both groups resemble each other. Thus, there were several testimonies about existential situations related to addictions of various kinds-alcoholism, smoking, and illicit drugs. In these cases, charismatic Catholics claim to have reached "liberation" by entering into an Alliance Community or a prayer group.

We recorded some Masses and encounters of healing and liberation, and in both we noted an emphasis on Mary and the Devil's strength. In the eyes of charismatics, "liberation" involves achieving a grace that neutralizes malignant forces that act in various aspects in the life of a person, generating a set of material and emotional problems.

Mary Most Holy is also part of the Gospel. You're dry, doubtful, you need to believe that God exists. It is because doubt that the miracle doesn't happen. Maria believed. You must invoke the name of God and not curse. Curses you utter with your own tongue. If nothing in your life works, it's your fault! You and your house were not meant to have spiritual illnesses (Healing and Liberation Encounter; Neighborhood: Guadalupe, 2012). ${ }^{19}$

Informants mentioned the festive character of the CCR, the praise, and the welcoming as important catalysts for adherence to the movement. In addition, in all the researched parishes, the Bible was a requirement. The coordinator in one of the groups said: "the Bible is the weapon of the Christian." For her, Christians must always be "armed". Indeed, the reading of the Bible is strongly encouraged in the CCR and it is a mark that identifies the charismatic Catholic (da Silva 2008).

Prayer, associated with musical praise, is also a reason for the attraction and permanence of charismatics in the Catholic Church. The CCR especially encourages glossolalia. According to da Silva (2008), glossolalia can be considered as an act of initiation of the new member, even if it can pose a barrier for the newly arrived. Fieldwork revealed that the movement's leaders make special appeals to the faithful to pray in tongues and to teach this practice to each other. The charismatic leadership stressed that this was the most basic and most important gift, because it is through it that the Holy Spirit acts and speaks. We also perceived that in the groups there was an insistent invitation to revive the charismatic identity, not only through the gift of tongues, but calling forth other charismas, such as prophesizing and experiencing visions. Such an identity-focused discourse makes sense in light of the expansion of the Communities of Life and Alliance, as the number of members in prayer groups decreases. These communities require a fuller, more consistent spiritual engagement.

It is necessary to be charismatic; I am called by the Charismatic Renewal! (Clapping). The prayer group cannot die, if it is docile to the Holy Spirit. The best way to reap the fruits is to

19 Research Report: "The crisis of Catholicism in the state of Rio de Janeiro and the paradoxical advancement of the new religious communities." 
welcome the Holy Spirit. Our religion is not immediatist as we see others out there. The problem is not to pass the dark valley of the shadows, the problem is to pass without the Holy Spirit (Meeting of Prayer Group; neighborhood: Praça Seca, 2012). ${ }^{20}$

Encouraging the exercise of a more intimate and emotional prayer on the part of charismatic Catholics confirms that the CCR diverges vis-à-vis tradition. If, on the one hand, the charismatic narratives extoll the Church's tradition as a value to be preserved, on the other hand, these same narratives also promote a rupture with tradition by stimulating such practices as "resting in the Spirit" (repouso no Espirito). This practice which makes the faithful fall to the ground suddenly in a kind of trance, saying they are possessed by the Holy Spirit, is more typical of Pentecostals than traditional Catholics. Thus, the CCR partakes of a vision in which

[... ] Religion does not necessarily have to offer theological or normative contents that strengthen the bonds with the religious community, but rather this relationship is strengthened by the institution's capacity to offer meaning to the community of believers, fostering a religious experience that is more subjective than objective. The institution needs to "touch the heart", to produce an emotional appeal. (Fernandes and Pitta 2006)

This would be a constitutive contradiction within the CCR: at the same time that it puts tradition to work to ensure the Catholic identity, it introduces to the ecclesial community at large a detraditionalization, which is the hallmark of rationalization processes-distancing Catholics from traditional, collective liturgical practices, toward an emotional, personalistic understanding of rituals. Here we see how the Weberian thesis of rationalization makes sense of the charismatization of the Catholicism that remains. In response to increasing religious diversification, new expressions of Catholicism emerge, and as the CCR shows, they are rationalized.

When assessing the differences between the CCR and the Communities of Life and Alliance, the charismatics we interviewed in Rio do not assign value to these different modalities of being charismatic. Thus, they argue that being charismatic does not entail an exclusive relationship with the CCR. For them, charismatic spirituality is something inherent to the church and not the prerogative of a single group. This discourse intends to reinforce the movement's Catholic identity and to avoid any kind of discrimination of its members within the Church.

Charismatic Catholics participate and have great sympathy for Life Communities like New Song (Canção Nova) and Shalom, both internationally known. These communities are deeply admired and guide the CCR's spirituality through their television programs and by commercializing religious products such as images of saints, rosaries, and countless objects in their stores and on their websites.

Regarding Life Communities, several respondents feel that they represent a way to return to the primitive church, and that they are God's answer to the current world, because of the breakdown of families. Confronted with this reality, the new communities offer a new family for its members. They would become the places in which the faithful would be able to carry out a fuller experience of God, consecrating themselves and living in and through the community. With different charismas, communities would have specific ways of acting in society. One of the informants outlined the difference between the CCR and the communities in this manner:

CCR is an institutionalized, structured movement, a national and global organization. Communities do not have any type of upper structure that leaves them in the same format. Each community has the freedom of evangelize according to their charismas. ${ }^{21}$

20 Research Report: "The crisis of Catholicism in the state of Rio de Janeiro and the paradoxical advancement of the new religious communities."

21 Research Report: "The crisis of Catholicism in the state of Rio de Janeiro and the paradoxical advancement of the new religious communities." 
The interviewees distinguish between the CCR and Church pastoral initiatives. In general, they defend the value of the spirituality of the charismatic movement, arguing that CCR participants seek a "deeper conversion", a life of more intense prayer. They seek to "live the renunciation of world", "are more cheerful in celebrations", "let themselves be led by the Holy Spirit", "live the charismas", and value the Bible by seeking to live according to its teachings.

For most of the charismatic respondents in Rio, Church pastoral initiatives are often "more closed" (fechadas), lacking spirit (desanimadas), demure, traditional, old, "with weak spirituality". Some other respondents in the CCR take a more tolerant position, in which they affirm the freedom of action of each group in Catholicism, in accordance to its own charismas and function in the church.

What we can perceive is that there are some misunderstandings, because the idea, the focus of all the spirituality of the Catholic Church is Christ himself; it's the Eucharist. Now, there are some who pray more, praise more. This does not mean that the CCR people are more Catholic than others. ${ }^{22}$

From the perspective of the charismatic interviewees, Catholicism loses supporters in Brazil mainly because Catholics have become "accommodated", meaning that they take their faith for granted and do not work hard to sustain it. They also see the lack of Catholic formation as a big problem. Indeed, for them, s/he who does not know the church sufficiently abandons it. In other words, they operate with the idea that there are "false Catholics", who would be free to leave the Church and become what they really are. This more reactive discourse concerning the loss of the faithful to other religions is more intense among Rio de Janeiro charismatics, even though it is also present in all the cities surveyed.

According to Novaes (2006), one of the fruits of a pluralist and secularized society is the rearrangement of beliefs and the breaking of bonds with religious institutions, where the result would be not only a deinstitutionalized religiosity, but the reinvention of traditions in a more exclusivist perspective. In their efforts to convert the whole church, charismatics express an exclusivist understanding of the bond that a Catholic should have with the Church, advancing a model that they deem to be the true one.

Charismatics critique the Church for what they perceive as its inefficiency in welcoming the faithful. They believe that other religions are more effective in this regard, which contributes to the desertion of Catholics. For them, the priest is an important figure who can both bring the faithful closer to the Church or keep them away from it. Other quantitative studies point to this dimension of welcoming to and affectivity within the community, as respondents justified their adherence because they feel good in the Church (Fernandes and Pitta 2006; Fernandes and Souza 2002).

The assessment that the vitality of a religion is predicated upon the interaction between religious leaders and the faithful, particularly upon the latter's sense of well-being, reveals the process of rationalization at work: the focus of religious institutions becomes the cultivation of individuality amid the pressing issues of everyday life. Religion becomes a balm; it becomes a space where the faithful and producers of the sacred enter into relations of (often commodified) exchange.

In one of the Communities of Life we analyzed in Rio de Janeiro, the call for institutional fidelity was evidenced by praise of the papacy, the emphasis on obedience to the norms of the community and on ecumenism with Pentecostal churches, as well as by less dispute among the different charismas. The leader of the Community participates in ecumenical encounters with Pentecostal Evangelical churches and counsels and provides spiritual direction to the faithful who seek it. If members want to participate in prayer groups, they must request permission and include this activity in the routine of the house. Here, we can see the intensity of the commitment and regulation of the difference between prayer groups and Communities of Life.

22 Research Report: "The crisis of Catholicism in the state of Rio de Janeiro and the paradoxical advancement of the new religious communities." 
In sum, extrapolating from the studied parishes, charismaticism in Rio de Janeiro reinforces Catholic identity and makes the CCR an instrument to prevent the desertion of the faithful. Practices of healing and liberation address the Devil and "spiritual diseases", just as in Neo-Pentecostal churches. The exclusivist praise of the movement and the emphasis on the distinction between the CCR and the other pastorals initiatives and religions may represent an attitude of confrontation of the Catholics in view of the advance of Evangelical churches.

\subsection{Silva Jardim}

With only 21,349 inhabitants, this municipality is located in the rural area of the state of Rio de Janeiro's coastal lowland. Its urban area has the characteristics of cities in the interior that concentrate commercial life and the principal church in its central region ${ }^{23}$.

Although there is not much consensus among historians on the specific origins of the municipality, it is safe to claim that it originated in the 18th Century. As is common in Brazil, the population nucleus began to form around a Catholic church, in this case, the Church of Santana that was renamed Our Lady of Lapa de Capivari in 1841. The main economic activity in the early period was agriculture, with the cultivation of coffee, sugar cane, and grains eventually gaining prominence. ${ }^{24}$ In 1890, during the Republican period, the municipality came to be called Silva Jardim.

In 2015 , the municipality had a low employment rate, with only $21 \%$ of the population employed with an average salary equivalent to $\$ 700$. The sanitation conditions in Silva Jardim are also very precarious: only $61 \%$ of households are adequately connected to the city's sewer system. ${ }^{25}$

The ten Catholics we interviewed in the city (five men and five women between the ages 23 and 71 years) had diverse profiles. In contrast to Laje do Muriaé, several of them reported having witnessed the change of religion among family members. However, they all claimed to be Catholics by family tradition. Still, among the current Catholics, we found cases of people who left Catholicism, participated in an Evangelical Protestant church, and returned to the Catholic Church after a certain period. The belief in the Eucharist was an important factor for the return. ${ }^{26}$ Thus, for several informants of the research, the main symbols of Catholicism that strengthen religious adherence are Mary and the Eucharist. These symbols are also heavily cultivated by the local priest, who takes care of fourteen chapels, in addition to the parish seat.

As previously seen in other sites, the CCR seeks to reinforce the Catholic identity through tradition, an emphasis on sacramental practices, and the unconditional loyalty to the Pope (Jurkevics 2004). We observed among respondents, even those who are no longer part of the CCR, that they have had some contact with a prayer group, whether encouraged by acquaintances (even by an old parish priest), or by curiosity and their own initiative. The most attractive elements in the CCR are: the "action of the Holy Spirit", "the revival of the Church", "the access to the word of God", "the strong prayer", "the Experience with God" and the greater freedom offered by Catholicism.

Regarding the Communities of Life, almost all the informants know them and can name some of them, such as New Song, Shalom, Ide, Maranatha, and Holy Trinity. The best known is New Song, which is headquartered in the city of Campinas, São Paulo, from where it engages in TV and radio outreach. The informants see these communities in a positive light, arguing that they contribute to evangelization.

The informants are more divided when it comes to the CCR as a movement. There was criticism of the alleged narrowness and self-interestedness of the movement, which is often perceived as not acting in favor of the community. Nevertheless, the informants also praised the CCR's most dynamic

23 The analysis of the city of Silva Jardim was partially published as Fernandes (2014, pp. 58-62).

24 See https://cidades.ibge.gov.br/brasil/rj/silva-jardim/historico. Accessed on 13 April 2018.

25 See https://cidades.ibge.gov.br/brasil/rj/silva-jardim/panorama. Accessed on 13 April 2018.

26 In a previous study, we had found a significant percentage of Pentecostals who migrated to Catholicism (18.7\%). Cf. (Fernandes and Pitta 2006). We hypothesized that these Pentecostals who entered Catholicism were "old", returning Catholics. 
practices. Finally, some took a more neutral position, stating that charismatics and other pastorals initiatives and groups are just different.

In this town, the faithful understand that the local priest is overloaded with work, especially in view of the long distances between the chapels that demand travel by car. Despite this challenge, the priest told us that it is practically unfeasible to secure financial resources for two priests, considering that the municipality is composed of mostly low-income households. Some members praise the priest and his commitment to the parish, but they consider it impossible that he can meet all the sacramental demands and pastoral activities. Therefore, they argue that if Catholics themselves took more initiative in promoting religious activities, so many of chapels would not be kept closed during the week, favoring the dispersion of Catholics to other Christian denominations. This interpretation that Catholics abandon the Church because of the lack of priests was recurrent among the interviewees. However, it is worth noting that former Catholics also acknowledge that there are important points of subjective identification with the narratives of the Evangelical worldview, be it Pentecostal or Neo-Pentecostal (Fernandes 2009).

Silva Jardim is a city with numerous Evangelical Protestant congregations, ranging from classical Pentecostals, such as the Assemblies of God, to Neo-Pentecostals. We heard reports that there is some discrimination against Catholics in the city, since most of the population is Evangelical. The priest assures the faithful that appearing isolated and being surrounded by Evangelical churches should not intimidate them, because the Catholic Church should be "universal and spread across the world".

The Catholics interviewed in Silva Jardim pointed out the difficulties that they perceive the Catholic Church is experiencing today: the absence of effective work with the young and, in the specific case of their city, the long intervals between Masses. They compare these long periods without Masses with the frequency and intensity of the celebrations in Evangelical churches, a comparison that, in their view, explains the expansion of the Pentecostals and Neo-Pentecostals and also shapes their attitudes of what Catholicism should be. In this regard, their emphasis falls on the construction of strategies for affirming Catholic identity in an environment of strong Evangelical presence:

In the city with the fewest Catholics in the state, there are Catholics concerned when they leave home, bringing the rosary in hand, their blouses with prints of the saints, ribbons, purses, stickers on the cars, their crucifixes around their necks and an expression on their lips: "The peace of Jesus and the love of Mary." Thus, we perceive the Church's efforts to combat desertions, not only with evangelization, but by the strengthening of Catholic identity. ${ }^{27}$

Some strategies in this environment of strong religious pluralism were designed by the local priest. In the field diary, we wrote:

As for the faithful, he [the priest] brought the church out to the street. The priest told [us] that when he came to town it was like the Catholic Church did not exist and many took it as if it did not exist anymore, because the vast majority of residents are Protestant. So, the priest began to make processions with more frequency. He started holding religious motorcades (carreatas) and festivals (festas) to show the city that the church was alive. ${ }^{28}$

There are those who do not see any difficulties with the Church that justify desertion from Catholicism. For some, there is greater authenticity in expressing religious adherence nowadays, and there is no longer fear in people of assuming a religious identity different from being Catholic. This perspective shows that the faithful are also aware of the changes in Catholic culture that we have analyzed theoretically and empirically. Indeed, as in other cities, some informants defended

27 Research Report: "The crisis of Catholicism in the state of Rio de Janeiro and the paradoxical advancement of the new religious communities."

28 Research Report: "The crisis of Catholicism in the state of Rio de Janeiro and the paradoxical advancement of the new religious communities." 
the position that the Church should be interested primarily in authentic or true Catholics: "There is no point in having 78 percent Catholics when 40 percent of them are Catholics of IBGE [the research institute in charge of the national census] ${ }^{29}$ " said a young teacher in Silva Jardim, meaning that a majority of those who declared themselves Catholics on the census are just so on paper.

This position demonstrates an adherence to the institutional discourse which concentrates on the defense of Catholic authenticity in times of more flexible choices. The prescriptions of the Catholic hierarchy highlight what they consider essential for the maintenance of this authenticity: the affirmation and knowledge of what it means to be a Catholic. The Catholic Church understands that the loss of the faithful is related to lack of training. However, research has shown that many Catholics with training on the rites and beliefs of the Church have abandoned it. So, there must be other important factors influencing this loss and the transformation of the logic of religious affiliation in Brazil, including the distance between temples and the accelerated and fragmented dynamics of modern life.

Another important finding in Silva Jardim reported by the informants themselves was that many who attend Masses and activities in the parish also take part in Spiritism and Umbanda. This attitude is criticized by them because they consider it inappropriate for a Catholic. All the same, such an attitude demonstrates how religious identity in Brazil is multifaceted and based on experimentation and looser religious bonds.

For many of the respondents, the explanation for the change of religion lies in the need to resolve personal issues more immediately and effectively, as well as in the scarcity of priests who are overburdened, as discussed above. Particularly in this city, the priest assumes a central role. The fact of being the only one priest in the city makes him the focal point of criticism, and simultaneously of praise, for his efforts to meet the needs of everyone. A chapel that is located $18 \mathrm{~km}$ from the parish seat undoubtedly exemplifies the challenge faced by a priest so heavily demanded by the faithful in this municipality.

Many parishioners in Silva are traditional Catholics who have been attending and actively participating in the Church for a long time. However, several of them have trajectories that intersect with other religious experiences. A woman reports that even though she was born "in a Catholic home", she started attending Umbanda because of her husband. Nevertheless, she returned to Catholicism because she "was not happy". Her testimony suggests that ordinary life events and conditions can promote the change of religion, not necessarily discontentment with the religion of origin. In this case, a difficult marriage was the determining variable in the process of religious mobility. Three years after experimenting with Umbanda, she and her husband returned to Catholicism, because, in her view, it possesses "something that charms" (alguma coisa que encanta).

There is certainly an institutional ambivalence and tension between, on the one hand, the need to expand and strengthen Catholicism in the face of the growth of Evangelical Protestantism in the municipality and, on the other hand, the vision that only authentic Catholics must remain in the community. This is illustrated in the following testimony:

A lady said a friend would come and talk to the priest because her grandson was using drugs and she didn't know what else to do. But this lady confided to the priest that the aforementioned friend was also going to a Protestant church. The priest then said to let her go; that he wasn't going to be worrying about Catholics who don't have a sense of the daily struggle and the Calvary that we have to go through. ${ }^{30}$

The interviewees in Silva Jardim value the communication vehicles that expand the Catholic message. Listening to the religious goods offered by Catholic TV and radio stations, such as Canção Nova, the TV channel 21th Century (Rede Século XXI), and the Life Network (Rede Vida), is part of

29 Brazilian Institute of Geography and Statistics.

30 Research Report: "The crisis of Catholicism in the state of Rio de Janeiro and the paradoxical advancement of the new religious communities." 
their daily routines. They also watch and listen to the programs of Father Marcelo Rossi, the famous "singing priest" with close ties to the CCR, and Father Antonio Marcos on Catedral Radio, a station that belongs to the Archdiocese of Rio de Janeiro.

As a small town with a strong rural component despite the proximity to the state's capital, Silva Jardim has low access to the Internet as a means to expand and cultivate the Catholic faith. The low levels of schooling and income of the informants are, likewise, a factor that restricts access to new technologies.

Some Catholics interviewed who do not act directly in a prayer group have a positive opinion of the CCR. They value the spirituality of the movement-its music, joy and prayers-and they feel as "Catholics of the movement". They justify not joining the group by because of conflicts between their work schedule and the times of the group meetings. I observed that the prayer group Our Lady of Graces is just another group in the parish of Silva Jardim. With an average attendance between five and twenty people, the group has a relatively low profile in the parish.

\section{Final Considerations}

This article analyzed the Catholic Charismatic Renewal in the state of Rio de Janeiro through qualitative research in four cities with different proportions of Catholics. In all of them, I found that the CCR is diverse in accordance with the local contexts, the trajectories of its leaders, and the theological orientations of the priest and the archdiocese. Generally, I perceived in all cities a more traditionalist perspective in the movement, in the sense of appreciation of the hierarchy, preservation of the doctrine, and affirmation of the bond with the Church. However, in Rio de Janeiro, less conciliatory discourses were more salient when explaining why Catholics are leaving the Catholic Church. In all the cities, charismatics laid the blame on the faithful themselves for the difficulties in staying in the Church, on account of their pursuit of purely pragmatic solutions to their problems, rather than seeking a deeper and more intense engagement with the faith. On the other hand, they also mentioned the lack of welcoming in the Catholic Church as one of the reasons for the desertion of the faithful.

Even though prayer groups continue to be the primary components of the CCR, they have not been able to maintain a high number of participants as they did in their early days. Instead, the healing and liberation encounters, as well as the Masses for this purpose, have greater power to attract longstanding charismatics and new Catholics, surpassing the dynamism of prayer groups meetings. In this regard, despite efforts to affirm a strong Catholic identity, the similarity between charismatic Catholics and Pentecostals persists, as discourses about the Devil, spiritual diseases, and liberation are especially prevalent in prayer groups and Masses of healing and liberation.

Paradoxically, the municipality with lowest proportion of Catholics in the state has a charismatic prayer group that does not stand out from other groups in the parish. Rather, surrounded by evangelical temples, the local Catholic Church chose to give public visibility to Catholicism through processions of saints, as well as the production and wearing T-shirts with religious engravings and various sacred objects that affirm Catholic identity. This municipality may point to the limits of using the CCR as a strategy to retain Catholics in a rural setting where there is intense religious competition. In this context, it would seem that traditional popular Catholicism recovers its protagonism.

The rationality of the CCR produces negotiations and tensions between the charisma and tradition. Thus, the movement expands charisma by inspiring new Communities of Life and Alliance that affirm tradition, even making use of mystical, "magical" elements, such as the gifts of revelation, healing, and prophecy. However, the CCR institutionalizes and rationalizes these mystical elements, making them the centerpiece of an individual and heavily mediatized and marketized spirituality and creating rules and regimented ways of life that it expects authentic Catholics, both old and new, to live by. In that sense, the two framing Weberian theses that I proposed-the proliferation of new religious expressions in the face of increasing religious fragmentation and the rationalized character of these new expressions-help to make sense of growth of the CCR in the state of Rio de Janeiro. 
Funding: This research was funded by Faperj Foundation, Grant number E-26/101.856/2010 and Cnpq-National Council of Scientific and Technological Development, Grant number 400483/2010-6.

Conflicts of Interest: The author declares no conflict of interest.

\section{References}

Braga, Antônio Mendes da Costa. 2004. TV Católica Canção Nova: "Providência e compromisso" X "mercado e consumismo". Religião E Sociedade 24: 113-23.

Camurça, Marcelo Ayres. 2008. Ciências Sociais e Ciências da Religião: polêmicas e interlocuções. São Paulo: Paulinas. Carranza, Brenda. 2000. Renovação Carismática Católica: origens, mudanças e tendências. Aparecida: Editora Santuário.

CNBB. 1994. Orientações Pastorais sobre a Renovação Carismática Católica. São Paulo: Paulinas.

da Silva, Leonardo Almeida. 2008. O Espírito sopra como quer? Consequências das Relações institucionais da Renovação Carismática Católica. Paper presented. Niteroi: Encontro Universidades Renovadas.

de Oliveira, Eliane Martins. 2004. O mergulho no Espírito Santo: Interfaces entre o catolicismo carismático e a Nova Era (o caso da comunidade de vida no Espírito Santo Canção Nova). Religião e Sociedade 24: 85-112.

Fernandes, Sílvia Regina Alves. 1996. Movimento de renovação carismática católica: ethos comum e antagônico em camadas populares no Rio de Janeiro. Revista da Universidade Rural. Seropédica/Rio de Janeiro, Universidade Federal Rural do Rio de Janeiro 18: 109-24.

Fernandes, Sílvia Regina Alves. 2009. Novas formas de crer: católicos, evangélicos e sem-religião nas cidades. São Paulo: Promocat.

Fernandes, Sílvia Regina Alves. 2010. Jovens religiosos eo catolicismo: escolhas, desafios e subjetividades. Rio de Janeiro: Quartet/FAPERJ.

Fernandes, Sílvia Regina Alves. 2014. Católicos e catolicismo (s) no Brasil: dinamizando os dados censitários. In O censo e as religiões no Brasil. Edited by Maria Clara Bingemer and Paulo F. C. Andrade. Rio de Janeiro: PUC Rio: Reflexão.

Fernandes, Sílvia Regina Alves, and Bryan Froehle. 2011. Revitalization Movements, Social Change, and Justice: Brazil's Toca de Assis in Global Perspective. In Interpretative Trends in Christian Revitalization for the Early Twenty First Century. Edited by J. S. O’Malley (org.). Lexington: Emeth Press.

Fernandes, Sílvia Regina Alves, and Marcelo Pitta. 2006. Mapeando as rotas do trânsito religioso no Brasil. Religião e Sociedade 26: 120-34.

Fernandes, Sílvia Regina Alves, and Luiz Alberto Souza. 2002. Desafios do catolicismo na cidade: pesquisa em regiões metropolitanas brasileiras. New York: Paulus.

Guerra, Lemuel. 2003. As influências da lógica mercadológica sobre as recentes transformações na Igreja Católica. Revista de Estudos da Religião, São Paulo 1: 1-23.

Hervieu-Léger, Danièle. 2000. Religion as a Chain of Memory. New Brunswick: Rutgers University Press.

Jurkevics, Vera Irene. 2004. Renovação carismática católica: reencantamento do mundo. História: Questões $\mathcal{E}$ Debates 40: 121-34.

Loura, Bruno Marinho dos Santos. 2014. RCC em Campos dos Goytacazes: efeitos de uma tradição polissêmica. Nova Iguaçu: Universidade Federal Rural do Rio de Janeiro.

Mariz, Cecília Loreto. 2001. Pentecostalismo, Renovação Carismática Católica e Comunidades Eclesiais de Base: uma análise comparada. Caderno CERIS, Ano I 2: 11-42.

Mariz, Cecília Loreto. 2003. A Renovação Carismática Católica Uma igreja dentro da Igreja? Civitas-Revista de Ciências Sociais 3: 169-86. [CrossRef]

Mariz, Cecília Loreto. 2005. Comunidades de vida no Espírito Santo: juventude e religião. Tempo Social 17: $253-73$. [CrossRef]

Mariz, Cecília Loreto. 2007. A sociologia da religião de Max Weber. In Sociologia da religião: enfoques teóricos. Petrópolis: Vozes. Edited by Faustino Teixeira. Petrópoli and Rio de Janeiro: Vozes, pp. 67-93.

Mariz, Cecília Loreto. 2009. Missão religiosa e migração: "novas comunidades" e igrejas pentecostais brasileiras no exterior. Análise Social XLIV: 161-87.

Mariz, Cecília Loreto, and Maria das Dores Machado. 1994. Sincretismo e trânsito religioso: Comparando carismáticos e pentecostais. Comunicações do ISER 40: 24-34. 
Norris, Pippa, and Ronald Englehart. 2004. Sacred and Secular: Religion and Politics Worldwidw. Cambridge: Cambridge University Press.

Novaes, Regina. 2006. Os jovens, os ventos secularizantes e o espírito do tempo. In As religiões no Brasil: continuidades e rupturas. Petrópolis: Vozes. Edited by Faustino. Menezes Teixeira: Renata, pp. 35-48.

Prandi, Reginaldo. 1997. Um sopro do Espírito-A Renovação conservadora do catolicismo carismático. São Paulo: Edusp.

Souza, Luiz Alberto. 1986. Secularização em declínio e potencialidade transformadora do sagrado. Religião e Sociedade 13: 2-16.

Stark, Rodney, and Roger Finke. 2000. Acts of Faith: Explaining the Human Side of Religion. Berkeley: University of California Press.

Steil, Carlos Alberto. 2004. Renovação Carismática Católica: porta de entrada ou de saída do catolicismo? Uma etnografia do Grupo São José, Porto Alegre (RS). Religião E Sociedade 24: 11-36.

Weber, Max. 1998. Sociologia da Religião. In Economia e Sociedade: Fundamentos da Sociologia Compreensiva. Brasilia: Ed. Universidade de Brasilia, vol. 1, pp. 279-418.

Weber, Max. 1999. A ética protestante e o espírito do capitalismo. São Paulo: Pioneira.

(C) 2019 by the author. Licensee MDPI, Basel, Switzerland. This article is an open access article distributed under the terms and conditions of the Creative Commons Attribution (CC BY) license (http://creativecommons.org/licenses/by/4.0/). 